\title{
Theoretical Regulation of Delimitation of Metal Level Decrease in the Furnace in Case of Pneumatic Dosing Device of Metal
}

Juraj Ružbarský, Rastislav Majerník

Faculty of Manufacturing Technologies with a seat in Prešov, Technical University of Košice, Štúrova 31, 08001 Prešov, Slovakia. E-mail: juraj.ruzbarsky@tuke.sk, rastislav.majernik@tuke.sk

Article deals with the during operation of pneumatic dosing device designed for die casting machines where the metal level in the furnace decreases stepwise by which the period of dosing of the filling mould is prolonged. We also deal the regulation of delimitation of metal level decrease in the furnace based upon the pneumatic principle.

Keywords: Theoretical Regulation; Die casting; Air pressure; Dosing device

\section{Acknowledgement}

This paper has been prepared within the project VEGA 1/0381/15 and KEGA 027TUKE-4/2014.

\section{References}

[1] BOLIBRUCHOVÁ, D., RICHTÁRECH, L. (2016). Possibilities of Using Al-Si-Mg Alloys with Higher Fe Content for Demanding Castings. In: Manufacturing Technology, Vol. 16, pp. 317-323, ISSN 1213-2489

[2] BORKOWSKI, S., INGALDI, M., SYGUT, P., KLIMECKA-TATAR, D. (2016). Stability of the Casting Process According to the Method BOST. In: Manufacturing Technology, Vol. 16, pp. 26-29, ISSN 1213-2489

[3] BLATNICKÝ, M., DIŽO, J. (2016). Design of a Three-Finger Robot Manipulator. In: Manufacturing Technology, Vol. 16, pp. 485-489, ISSN 1213-2489

[4] JENČURÁKOVÁ, D., PALENČÁR, R. (2016). Optimizing Management of the Measurement System of the Technological Process. In: Manufacturing Technology, Vol. 16, pp. 107-113, ISSN 1213-2489

[5] MACHUTA, J., NOVA, I. (2016). Analysis of Heat Transfer Conditions in the Sand and Metal Moulds and Their Effect on the Solidification of the Casting. In: Manufacturing Technology, Vol. 16, pp. 380-384, ISSN 1213-2489

[6] NOVÁ, J., NOVÁKOVÁ,J., BRADAČ,J. (2006). Technologie I, TU Liberec, p. 89

[7] PAŠKO, J. et al. (2014). Die casting defects of castings from silumin. In: Applied Mechanics and Materials, Vol. 2014, No. 510, pp. 91-96.

[8] RAGAN, E. et al. (2007). Liatie kovov pod tlakom, FVT 2007, Prešov, 392 p.

[9] RUŽBARSKÝ, J. (2014). Dynamics of core taking out at die casting. In: Applied Mechanics and Materials, Vol. 2014, No. 616, pp. 244-251.

[10] RUŽBARSKÝ, J., PAŠKO, J., GAŠPÁR, Š. (2014). Techniques of die casting. RAM-Verlag, 199 p. 